\title{
The Potential Role of Membrane Technology in the Removal of Microplastics from Wastewater
}

\author{
Adewale Adewuyi*, Abisola Joan Campbell \& Olalere G. Adeyemi \\ Department of Chemical Sciences, Faculty of Natural Sciences, Redeemer's \\ University, Ede, Osun state, Nigeria \\ Submitted: 24/3/2021. Revised edition: 7/4/2021. Accepted: 7/4/2021. Available online: 15/7/2021
}

\begin{abstract}
The presence of microplastics in water is a serious environmental problem. Although several approaches have been employed to tackle the problem, the use of membrane technology in addressing this problem remains encouraging but with limitation such as fouling and chemical instability which can be circumvented. This review identifies the presence of microplastics in water and the role of membrane technology in tackling the removal of microplastics in water. The study revealed the presence of microplastics in different water sources as well as the negative impact of microplastics on aquatic animals. Unfortunately, lack of proper management of plastic wastes has led to an increase in the presence of microplastics in the environment. Despite the profound performance by membrane technology towards the removal of microplastics in water, there is need to further improve on the limitations exhibited by this technology. However, there is no doubt that membrane technology remains an outstanding technology for the removal microplastics in water.
\end{abstract}

Keywords: Microplastics, Membrane bioreactor, Plastics, Ultrafiltration, Wastewater treatment

\subsection{INTRODUCTION}

Water pollution is a global challenge which is taking a new dimension towards emerging micro contaminants such as the emergence of microplastics in water. They are tiny plastics with diameter which is less than $5 \mathrm{~mm}$. Contamination of environmental water system with microplastics has become a serious global issue due to the disastrous impact on human beings and aquatic environment. An estimation of about 8.3 million tons of plastic had been produced since the 1950s with about $9 \%$ of production recycled leading to the accumulation of about $81 \%$ in landfills and environmental water bodies [1-3]. This has continuously increased the emergence of microplastic wastes entering the aquatic environment. Large number of plastics are used in packaging and when discarded, they get into the environment and eventually, the water bodies. These packaging plastics includes, polystyrene, polyethylene, polyvinylchloride, polypropylene, and polyethylene terephthalate. Anthropogenic activities are a pointer to plastic degradation resulting in the abundance and distribution of microplastics in aquatic environment [4]. Unfortunately, lack of proper management of plastic wastes has led to an increase in its presence in the environment $[5,6]$ resulting in bioaccumulation. When ingested by humans and aquatic organisms, microplastics can cause the obstruction of digestive tract, and bioaccumulate in the bodies with some health 
consequences [7, 8]. Studies have shown that they are capable of increasing mortality of aquatic lives [9], damage DNA and induce neurotoxicity in bivalves $[10,11]$, which are strong indications why they must be removed from water systems [12]. Previous researches have shown that microplastics can adsorb other contaminants in water when they come in contact with some of these cocontaminants in water includes metals $[13,14]$, pharmaceuticals and personal care products $[15,16]$ and other organic pollutants [17]. Other studies have shown the presence of microplastics in air [18], food [19], surface waters [20], soils [21], drinking water [13] and sediments [22]. Washing machines used at homes and sometimes for commercial purposes have been identified as a source of introducing fibers from synthetic textiles to the environment with a reported production of 1900 fibers per wash by a single garment [23], other reports revealed an average concentration of $7360 \mathrm{~m}^{-2} \mathrm{~L}^{-1}$ in polyester fleece fabrics and 110,000 fibers per garment [24] while and average of $6,000,000$ fibers from typical $5 \mathrm{~kg}$ load of polyester fabrics was reported by De Falco et al. [25]. Apart from this, used automobile tires, pellets waste from plastic industries, and scraps from paints have also been reported as sources of microplastics in the environment $[26,27]$.

Studies have revealed the presence of fragments of microplastics in oceans $[28,29]$. Although few, there are reported information on the presence of microplastic in tap and bottle water [30-32]. Moreover, other studies have reported the presence of microplastic in surface and ground water from different parts of the world. Table 1 shows the presence of microplastic in surface water from different countries. Most studies reported the presence of microplastic in fresh surface water. Study on river Seine in Paris reported an amount of 3-108 $\mathrm{m}^{-3}$ [18] while $1.94-17.93 \mathrm{~m}^{-3}$ was reported for river in Chicago, USA [33] in USA. Study by Baldwin et al. [34] reported the presence of plastics in 107 samples from 29 great lakes in USA with amount of microplastics ranging from $0.05-32 \mathrm{~m}^{-3}$. The dominant microplastic varied, however, in most surface water reported, fibers remained the most dominant type of microplastic particles. The amount (0.16-5.3 $\left.\mathrm{m}^{-3}\right)$ of fiber reported in water samples by Lenaker et al. [35] is similar to values $\left(0-22.8 \mathrm{~m}^{-3}\right)$ reported by Baldwin et al. [34] for 29 Great Lakes tributaries.

\subsection{DEGRADATION, SHAPE AND SIZE OF MICROPLASTICS}

The intra and inter molecular bonds in plastic may mostly be affected by oxidative, photo, hydrolytic and thermal degradation with photodegradation being the most effective means of degrading plastic when it gets into the environment. When degraded, plastic may become macroplastics $(>25 \mathrm{~mm})$, mesoplastics $(5-25 \mathrm{~mm})$, microplastics $(<5 \mathrm{~mm})$ and nanoplastics $(<0.1 \mu \mathrm{m})$. The oxidative degradation may be thermally or photo induced. The process provides and allows oxygen to have access to the polymer bonds causing the formation of carbonyl (CO) and hydroxyl (HO) groups, which promotes the degradation process, breaking down the covalent bonds in the plastic to produce free radicals that accelerates the degradation process [36]. During thermal degradation, the plastic is mostly broken down at a temperature range of 375 to $500{ }^{\circ} \mathrm{C}$. When hydrolytic degradation occurs, covalent bonds are the main target 
resulting in reduction of molecular weight. Although biodegradation is possible but the resultant effect is negligible and may lead to the formation of very toxic molecules that are environmentally unfriendly. It has become well understood that most of the biodegradation processes lead to incomplete degradation or may introduce other highly toxic substances to the environment; some of which are far more toxic than plastic itself.

Tables 1 Presence of microplastic in surface water from different countries

\begin{tabular}{|c|c|c|c|c|c|}
\hline Source & Country & $\begin{array}{l}\text { Surface } \\
\text { water } \\
\left(\mathbf{m}^{-3}\right)\end{array}$ & $\begin{array}{l}\text { Sediment } \\
\left(\mathrm{kg}^{-1}\right)\end{array}$ & $\begin{array}{l}\text { Dominant } \\
\text { microplastics }\end{array}$ & Reference \\
\hline $\begin{array}{lr}\text { Yangtze } & \text { River } \\
\text { shores } & \text { and } \\
\text { Chongming } & \text { Island } \\
\text { rivers } & \end{array}$ & China & $0-259$ & $10-60$ & $\begin{array}{l}\text { Polyethylene, } \\
\text { polypropylene, } \alpha \text { - } \\
\text { cellulose }\end{array}$ & [89] \\
\hline Tampa Bay & USA & 940 & $30-790$ & NR & [90] \\
\hline $\begin{array}{l}\text { German } \quad \text { Baltic } \\
\text { coast }\end{array}$ & Germany & $0-5000$ & NR & NR & [91] \\
\hline $\begin{array}{l}\text { Drinking water } \\
\text { treatment plants }\end{array}$ & Germany & $0-7$ & NR & $\begin{array}{l}\text { Polyethylene, } \\
\text { polyamide, } \\
\text { polyester, } \\
\text { polyvinylchloride }\end{array}$ & {$[32]$} \\
\hline $\begin{array}{l}\text { Stream, river and } \\
\text { lake }\end{array}$ & USA & $0.06-19.10$ & $\begin{array}{ll}32.9 & \text { to } \\
6229 & \end{array}$ & $\begin{array}{l}\text { Polyethylene, } \\
\text { polypropylene, } \\
\text { terephthalate }\end{array}$ & {$[35]$} \\
\hline Seine river & France & $3-108$ & NR & Fibers & [18] \\
\hline Rivers & USA & $\begin{array}{l}1.94 \\
17.93\end{array}$ & NR & Fibers & [33] \\
\hline Great lakes & USA & $0.05-32$ & NR & Fibers & [34] \\
\hline $\begin{array}{l}\text { Surface waters } \\
\text { and sediments }\end{array}$ & $\begin{array}{l}\text { Hong } \\
\text { Kong }\end{array}$ & $51-27,909$ & $49-279$ & $\begin{array}{l}\text { Polypropylene, } \\
\text { polyethylene, } \\
\text { ethylene, propylene, } \\
\text { styrene, acrylonitrile }\end{array}$ & [92] \\
\hline Lagoon of Venic & Italy & NR & $672-2175$ & $\begin{array}{l}\text { Polypropylene, } \\
\text { polyethylene }\end{array}$ & [93] \\
\hline
\end{tabular}

$\mathrm{NR}=$ Not recorded

As revealed by studies in literature, the current confirmation of the presence of microplastics in water and the danger it may pose, suggests the need to understand possible means of mitigating the danger microplastics may cause by removing them from water. Therefore, this review aimed at reporting the role of membrane technology in the removal of microplastics from wastewater.

Since microplastic originates from the breaking down of plastic, they can have different size, colour and shape. They can be recognized according to their morphology which may be fiber (Filament and lines), fragment, sphere (bead, granules and pellets), foam and film [37]. Study by Paul-Pont et al. [38] and Masura et al. [39] revealed the sizes, shape and colour of microplastic as shown in Figure $1 \mathrm{a}$ and $\mathrm{b}$; although this may not represent the entire wide range of possible size or shape of microplastics found in water bodies.

Furthermore, analysis carried out on wastewater, sludge and lake water samples from Finland by Lares et al. [40] revealed the presence of polyester, polyethylene, polyamide and polypropylene as shown in Figure 2. 

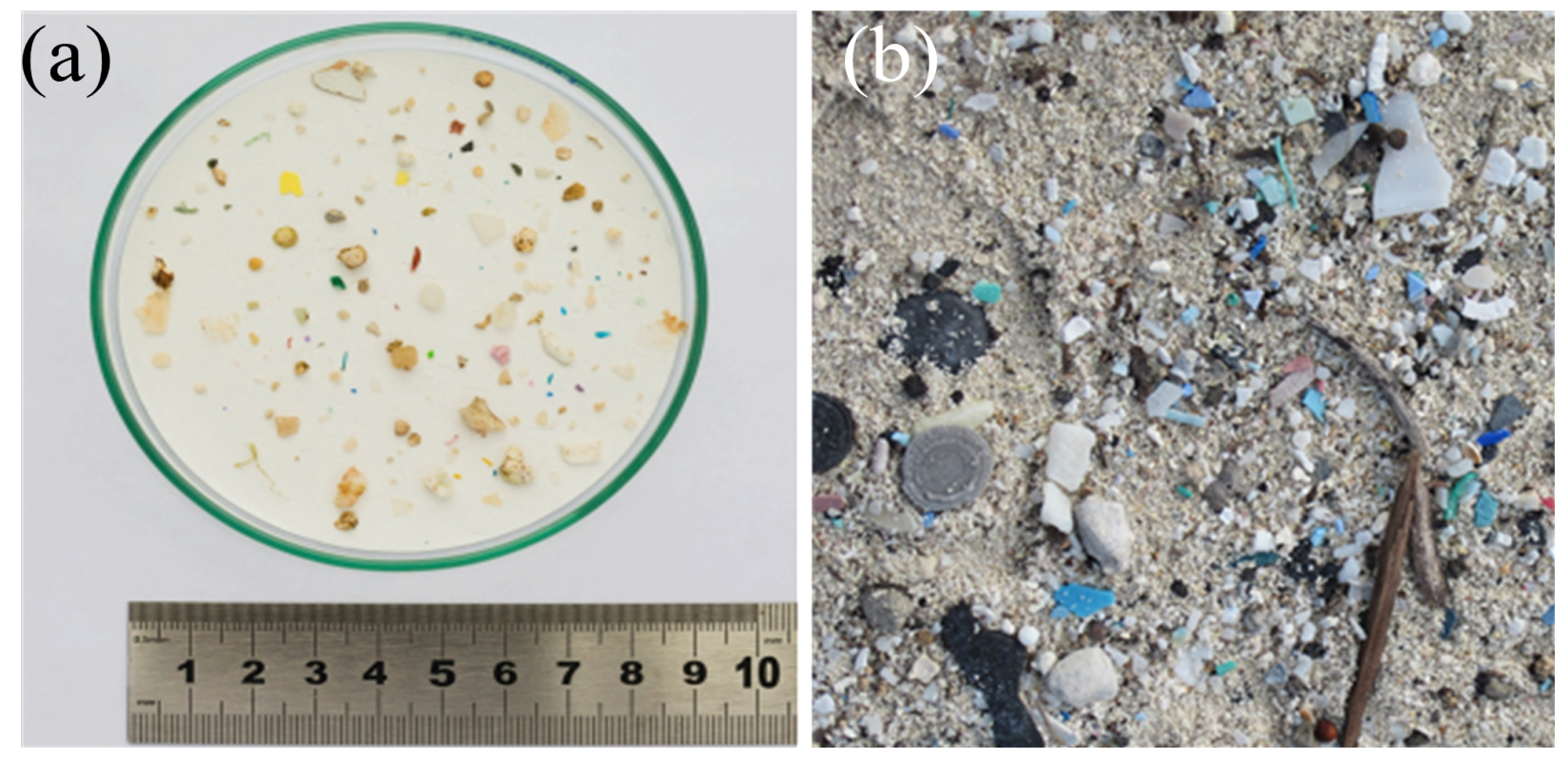

Figure 1 Shapes and sizes description of microplastics from sea (a [43], b [44])
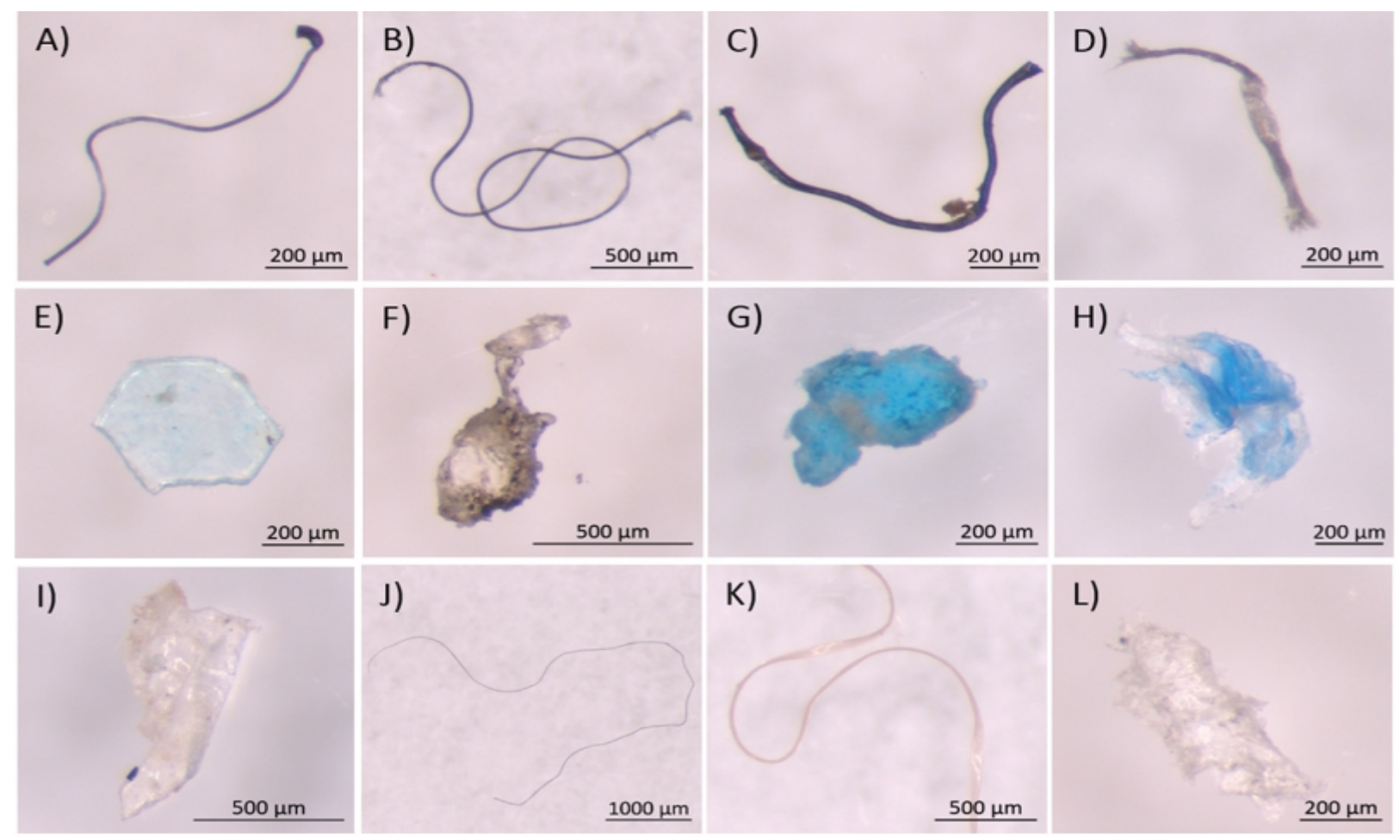

Figure 2 Different polymers detected in different stages of water sample analysis from Finland [40]

Microplastics are typically classified as plastics $<5 \mathrm{~mm}$ or in the range $1 \mu \mathrm{m}$ to $5 \mathrm{~mm}$ [41]. The synthetic spheres, microbeads and fibers are commonly found in the environment and when they get into freshwater and terrestrial, they become difficult to remove. The shape is determined by the original degrading plastic that forms the microplastic, residence time in the 
environment, and degradation process involved. Study by Rodríguez-Seijo and Pereira [42] revealed that the more the resident time of the microplastic in the environment, the smoother and more rounded the edge becomes. The difference in size and shape of microplastics makes it difficult getting rid of them from the environment [43]. When they exist in the environment, they are categorized into primary and secondary microplastics. The size and shape of primary microplastics are well defined examples are microbeads, pellets, and granules. The secondary microplastics are formed from the fragmentation and breakdown of large plastic debris which are already existing in the environment. They are the most commonly found in the environment resulting from mechanical impact and photodegradation.

\subsection{Health Impacts of Microplastics}

It is evidence that microplastics have been found in many species of organisms which have been detected in fish, avian species, and invertebrates [44]. Scherer et al. [45] has reported the presence of microplastics in algae and Daphnia magna. Microplastic has also been reported by Weber et al. [46] in Gammarus pulex. The presence of microplastic in these organisms have resulted in many environmental and health implications [47]. This may include starvation, gastrointestinal tract problems and even death [48]. When microplastics persist in the environment they may undergo certain reaction which may lead to other products that are more toxic than the microplastics. Some of these reactions are promoted by light, heat, and some other environmental factors. Some of the additives added to plastic during production are lipophilic and when they leach from the microplastic could penetrate the cell membranes and interrupt the biochemical reactions taking place in the cell causing health problems [36]. Apart from this, the monomers for the microplastics can get into the environment when it degrades, these monomers like ethylene chloride, vinyl chloride, etc are toxic and capable of causing cancer and abnormalities [48] or death. Previous study has shown that additives (triclosan) and pollutant such as polybrominated diphenyl ether (PBDE)-47 (5-30\%) from polyvinyl chloride are capable of leaching into the environment and being absorbed into the tissues of lugworms [49] which can lead to an increase in oxidative stress and mortality. However, study by Rodriguez-Seijo et al. [42] on the effect of low density polyethylene pellets without additives on earthworms had no negative effect on growth but revealed inflammation in the gastrointestinal tract and epithelial damage. A lot of marine animals are killed yearly from entanglement with plastic or from plastic ingestion [50]; similar observation has been reported for dogs, rats and rats [51, 52]. Andrades et al. [53] further investigated the relationship between scavenging behavior and ingestion of plastic in turtles, Chelonia mydas. Results from the diet analysis revealed that turtles scavenged and ingested plastics which indicates the danger with the widespread and current increase in the amount of plastic in the environment may cause.

\subsection{QUANTIFICATION AND REMOVAL OF MICROPLASTIC IN WATER}

It is important to correctly quantify, manage and treat water contaminated with microplastics in order to avoid the negative impact it may have on aquatic organisms, human and quality of water. Several approaches have been developed over time; however, they suffer from one disadvantage or the other. Although, 
currently, no standard procedure has been established for the evaluation or assessment of microplastics in water or soil; it is important to rely on existing standard analytical procedure of environmental impact assessment. However, developing a suitable sampling and pretreatment method is important because currently there are challenges in this area. These challenges are pronounced because the size of microplastics maybe $<1 \mathrm{~mm}$ which makes it difficult to easily quantify and characterize them in sample matrix. Sometimes, due to the small size, they can adsorb organic and inorganic substances from the environment which can interfere with the method of quantification, characterization and analysis. Overtime, different approaches have been used for samples collections and analysis. The different approaches also depend on the sources, site and point of collection of the samples. An illustration of this regarding ocean as an example was recently reported by Malankowska et al. [54] to indicate the different steps of sample processing depending on the section of ocean as described in Figure 3.

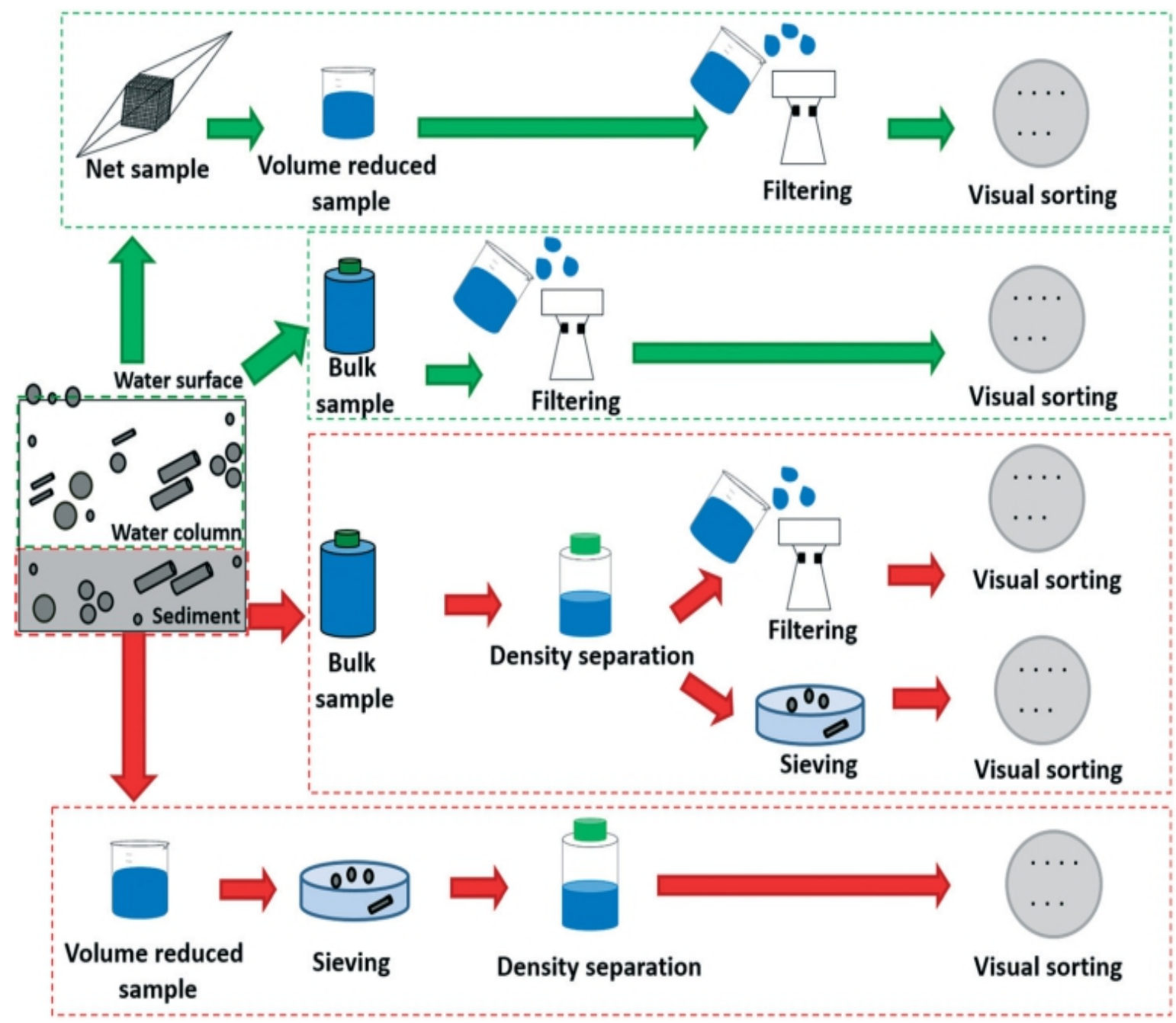

Figure 3 Stages in sample processing depending on the section of the ocean [54] 
Several methods have been developed to remove microplastics from water. The use of oxidation with $\mathrm{H}_{2} \mathrm{O}_{2}$, alkaline digestion and Fenton's reagent have been reported [55-58]. Despite the several methods known, membrane technology has proven to be an efficiently established process for the removal of microplastics from wastewater systems [12, 40, 59], with optimized removal performance greater than $97 \%$. Use of membrane technology for treatment of wastewater contaminated with microplastics is gaining interest because of the wide range of properties such as large surface area and porosity exhibited by membranes with excellent treatment capacity towards the removal of microplastics.

\subsection{Removal of Microplastic from Water by Membrane Technology}

Membrane separation is characterized by a selective barrier that selectively allows the passage of some substances while other substances are stopped making use of pores as semi-permeable membrane. In water treatment, the semipermeable membrane allows water to pass through while pollutants are removed via sieving and diffusion mechanisms. For effectiveness, the process requires the use of pressure as a driving force for the required separation. Different types of membrane technologies have been identified over time. The distinction may be based on membrane properties and principle of separation. Membrane technology is currently receiving interesting attention in the removal of microplastic in water; it has the capacity to treat both municipal and industrial wastewater. It is cost effective with maximum removal and recovery capacity. The process is effective due to the fact that membrane technology has the potential to replace energy-intensive conventional technologies as a result of their simplicity, low energy consumption, good stability and operational flexibility [54]. Apart from this, it has the advantage of being able to handle or process large amount of water samples with excellent facile control that can be scaled-up which gives better application advantage over other known methods for industrial scale application. Based on size and the mechanism of separation, membrane process may be classified into reverse osmosis, dialysis, microfiltration, nanofiltration, ultrafiltration, membrane bioreactor, dynamic membrane, and electrodialysis [60]. An illustration of the different possible membrane process is shown in Figure 4 as described by Lee et al. [61].

Removal by catalytic processes has also been used; unfortunately, it may release organic by-product which creates more difficulty suggesting that the separation method by membrane is superior. The growing demand for clean water makes it challenging to use conventional methods for water treatment; therefore, it is important to embark on a method that can handle large volume of water during treatment. The need for handling large volume of water further shifts attention towards membrane technology.

\subsection{Microfiltration}

Microfiltration removes particles higher than $0.08-2 \mu \mathrm{m}$ and operates within a range of $7-100 \mathrm{kPa}$. An efficient microfiltration membrane should have high chemical resistance, low flow resistance and well organized and structured pore size distribution. It may be used for the removal of residual suspended particles as a pretreatment step for reverse osmosis. This has also been used in membrane bioreactor as a combination steps for wastewater treatment. Its application is usually limited by membrane fouling as a result 
of suspended solids in the feed stream. Apart from this, accumulation of particles on the external membrane surface is reversible just as the deposition of particles on the internal pore structure is often also reversible. Microfiltration membranes fall between ultrafiltration membranes and conventional filters. Microfiltration membrane function with an average pore diameter which is larger than the diameter of the particle capable of permeating the membrane. It is capable of removing particles on its surface and in its interior.

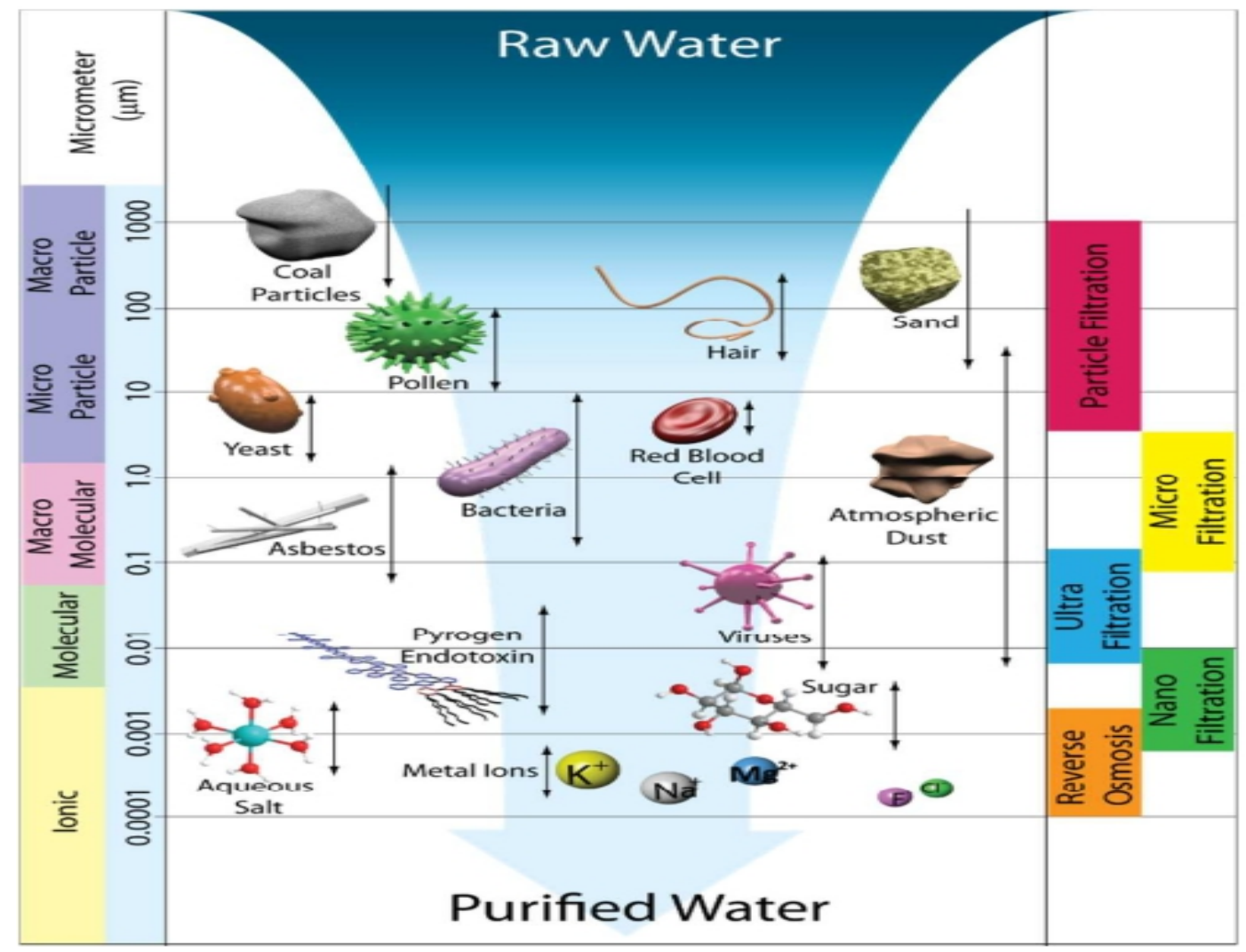

Figure 4 Schematic illustration of membrane filtration spectrum in the average pore diameter of the membranes [61]

To select a suitable microfiltration membrane, the nature of the solute and process fluid, molecular weight of the solute and operating parameters $(\mathrm{pH}$ and temperature) play important role in the selection. It is also important to consider cost, regeneration capacity and sustainability when considering microfiltration in wastewater treatment. Generally, the operational mechanism of microfiltration relies on the geometry [62]. During the separation, particles which are larger in size than that of the microfiltration membrane pores are removed via sieving mechanism, however, particles which are smaller in size than the pores of the microfiltration membrane are partially removed depending on the design of the membrane. Several forms of microfiltration membranes have been reported; they include, polymeric, ceramic, and nanocomposite microfiltration membranes. Reneker and Chun [63] reported the production of nanofibrous membrane in the submicron 
to nanometer-scale that can be used as microfiltration membrane. Other polymeric materials commonly used in this regard are poly(vinylidene fluoride), polysulfone, polyamide, poly(ether sulfone), polyether ether ketone, poly(tetrafluoro ethylene) and polycarbonate. Study by Abadi et al. [64] revealed the performance of ceramic membrane, related performance was reported by $\mathrm{Li}$ et al. [65]. The use of ceramic microfiltration membrane comes with a major advantage of achieving filtration without subjecting the filtration process to chemical pretreatment which reduces production cost. It became obvious that despite the high fluxes, porosity and hydrophilic surfaces exhibited by ceramic microfiltration membranes, they still show a few drawbacks [64]. Most currently used ceramic microfiltration membranes are produced from aluminum oxide, titanium oxide, and zirconium oxide. Sources as raw material for production of ceramic microfiltration membranes include, sepiolite, kaolin, and dolomite. Efforts have been made in the production of nanocomposite microfiltration membranes as means of filtration which can serve as potential means of treating water contaminated with microplastics. Preparation of nanocomposite microfiltration membranes may include the incorporation of inorganic nanoparticles such as aluminum oxide, titanium oxide, and zirconium oxide [66]. Microfiltration membranes have found application in water purification due to its exhibited properties. However, for better efficiency, it is better to couple microfiltration with other methods of water treatment especially in the removal of microplastics in water.

\subsection{Ultrafiltration}

Ultrafiltration makes use of an asymmetric ultrafiltration membrane at low-pressure in the range 1-10 bar. The pore size is in the range $1-100 \mathrm{~nm}$ with low energy consumption and high separation efficiency [67]. Ultrafiltration can remove particles higher than 0.005 $2 \mu \mathrm{m}$ and operates within a range of 70$700 \mathrm{kPa}$. The ultrafiltration membrane operates mainly on sieving process. It can replace or cofunction with existing methods like flocculation, sedimentation and coagulation in wastewater treatment. Although ultrafiltration is less active in removing low molecular weight compounds, it may be incorporated as a sub or co-process into water treatment processes for effective removal of low molecular weight compounds in water. In this instance, it may be integrated with coagulation in water purification. Although both coagulation and ultrafiltration can be used for the removal of organic molecule in water, they are not designed to effectively remove microplastics in water [12]. Studies have reported the removal of microplastics from water using coagulation and ultrafiltration [68, 69] with the removal of polyethylene in water using Fe-based coagulation. Variation in $\mathrm{pH}$ had significant effect in the use of Fe-based coagulant and ultrafiltration which exhibits an efficiency up to $90.9 \%$ that was attributed to high adsorption capacity [69]. Furthermore, polyethylene has been reportedly removed completely from water system using ultrafiltration membrane process due to its slight fouling and pore diameter which was induced after coagulation with Al-based salts [68]. Recently, Shahi et al. [70] reported the removal of microplastics of size range 10-100 $\mu \mathrm{m}$ using alum coagulant and alum combined with cationic polyamine-coated sand. In the study, cationic polyamine-coated sand combined with $20 \mathrm{mg} \mathrm{L}^{-1}$ of alum exhibited the highest percentage removal $(92.7 \%)$. A study revealed that improvement of ultrafiltration for water 
purification may be obtained by micellar and polymer enhanced ultrafiltration membranes [71]. Micellar enhanced ultrafiltration is selective towards target pollutant which makes it unique and specific. It involves the use of surfaceactive agent to remove pollutants in water which depends on electrostatic forces of interaction. It is also evident that the use of ultrafiltration membrane in conjunction with coagulating agents or surface-active agent results in high flux and outstanding water purification compared to conventional membrane processes [72]. A typical example of indigenously developed polyacrylonitrile based ultrafiltration membrane by Muthumareeswaran et al. [71] is presented in Figure 5.

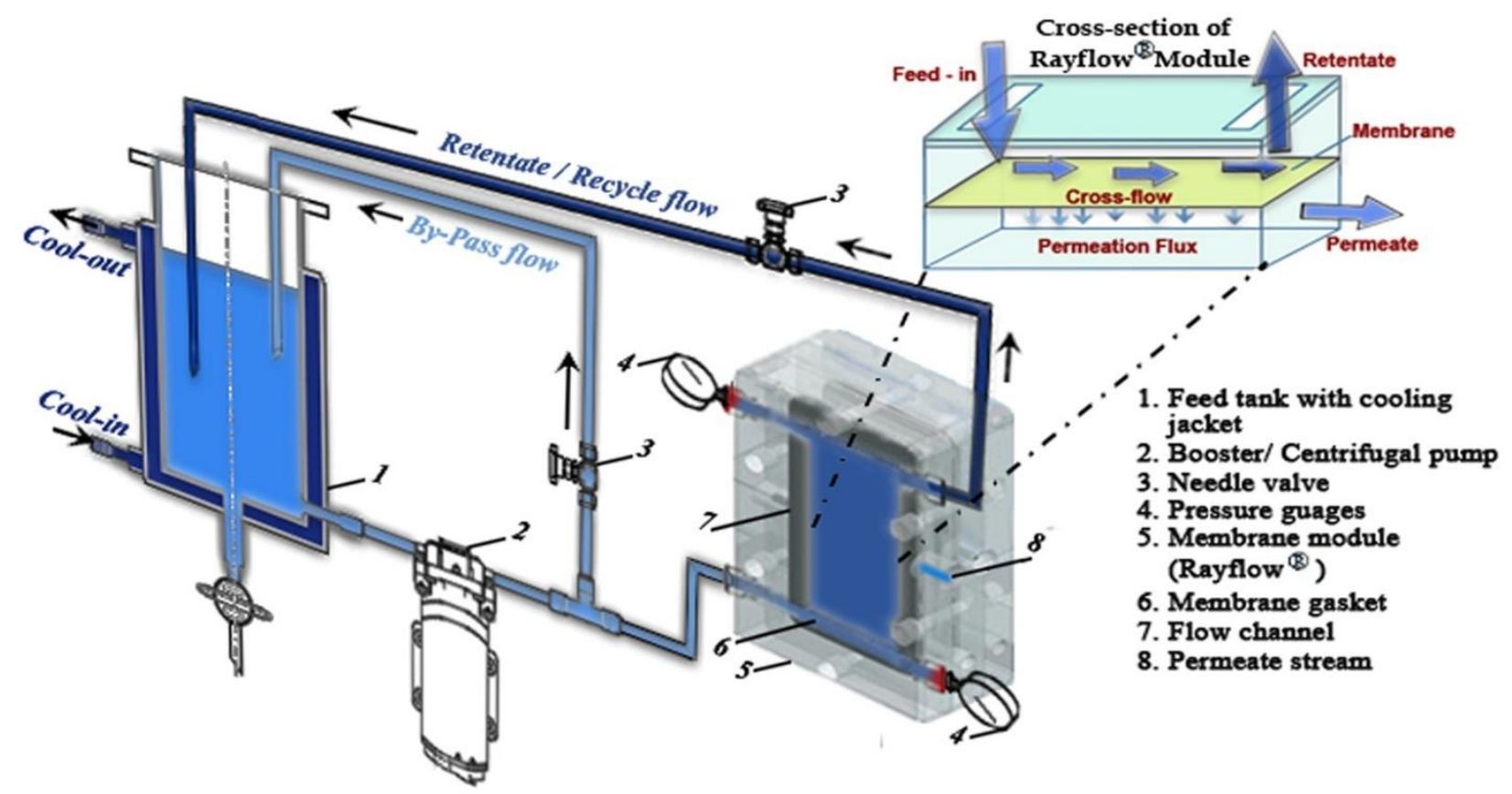

Figure 5 Ultrafiltration membrane for effective removal of chromium ions from potable water [71]

Although the polyacrylonitrile based ultrafiltration membrane was examined for the removal of chromium ions in water and with a rejection capacity greater than $90 \%$, the membrane may serve as a potential resource for the removal of microplastics in water. The study revealed that, to improve on the functionality of the polyacrylonitrile based ultrafiltration membrane, the sheets were modified by hydrolyzing them with $1 \mathrm{~N} \mathrm{NaOH}$ at $42.5^{\circ} \mathrm{C}$ feed temperature using cross-flow velocity of $0.72 \mathrm{~ms}^{-1}$ at $1 \mathrm{bar}$ transmembrane pressure. The modification and rejection mechanism are illustrated in Figure 6.

The modification resulted in a reduction in size which further indicates that this membrane will be useful in the ejection of microplastics in water. 


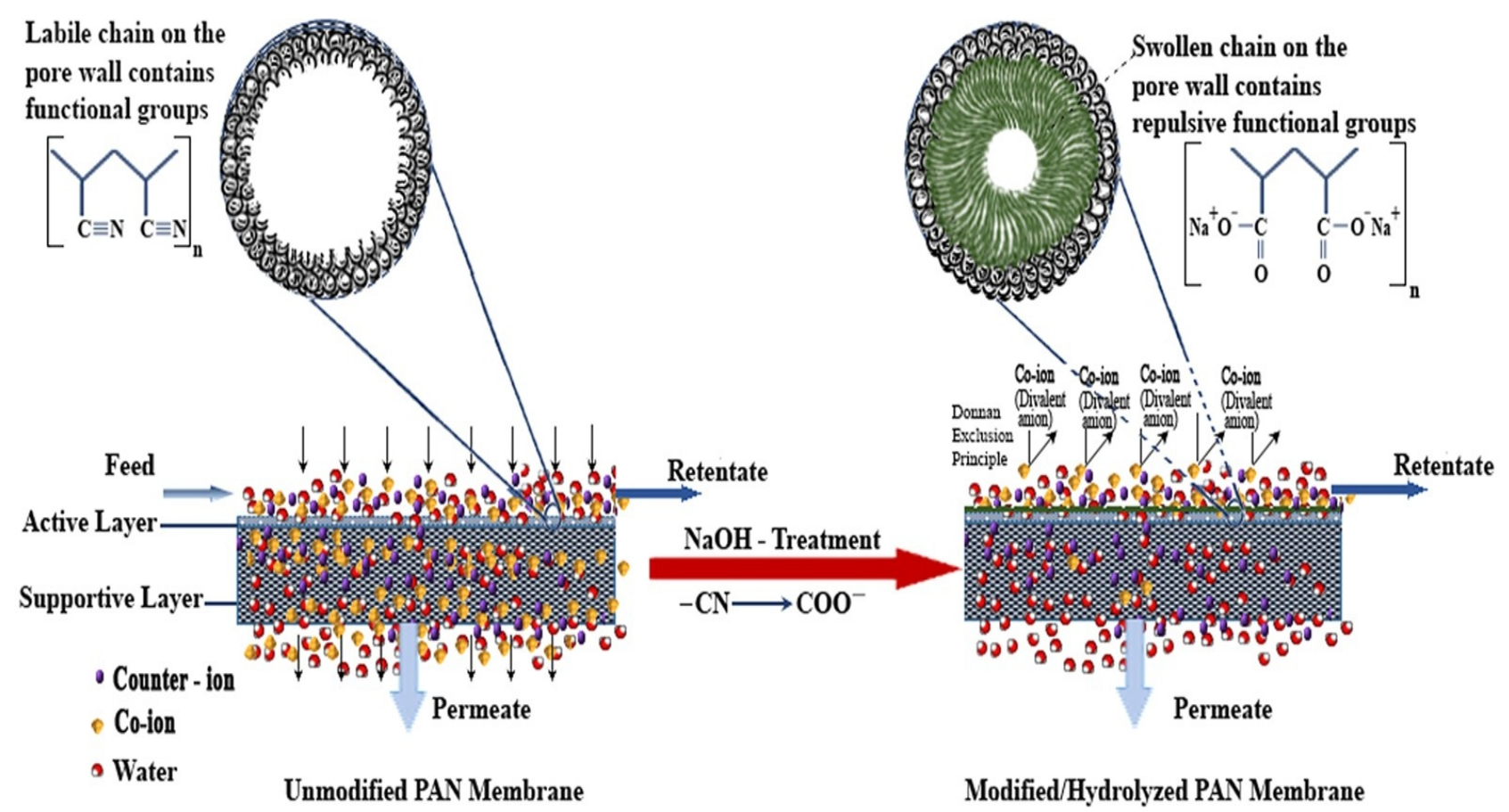

Figure 6 Surface modification and its rejection mechanism of co-ions via polyacrylonitrile ultrafiltration membrane [71]

The operations of micro and ultrafiltration are similar because the mode of separation involves the sieving of particle through membrane pores. The pore size is about $0.01-0.1 \mu \mathrm{m}$, it can filter dissolved macromolecules in the size range of 0.01-0.2 $\mu \mathrm{m}$. This capacity has given it application in water remediation, and in wastewater treatment. The ease of fabrication, high flux and simple operation system has facilitated the use of ultrafiltration in water treatment. The use of polymers in the fabrication of ultrafiltration membrane is gaining interest in water purification. The possibility of being able to recycle and regenerate for reuse over time makes it outstanding. Therefore, the selection of material for the production of ultrafiltration membrane depends on the physicochemical properties of the polymer [73]. Among the polymer sourced ultrafiltration membranes, flat sheet and tubular membrane modules with diameter 1-3 $\mathrm{cm}$ have low packing density which makes them expensive; however, the stacked modules can bear high pressure based on their design. Despite their usefulness, these membranes are susceptible to membrane fouling resulting in low treatment efficiency [74]. However, due to the disadvantages of fouling, they are replaced by spiral wound and hollow fibre structure with better performance in water treatment. The spiral wound membrane module remains the most commonly used for ultrafiltration membrane processes [75]. Ultrafiltration membrane is presently receiving attention in photocatalysis with treatment in wastewater. Such photocatalytic ultrafiltration membranes are produced with the incorporation of inorganics [76].

\subsection{Nanofiltration}

These are membranes used on solution diffusion principles involving the diffusion of monovalent ions. It has the capacity of rejecting particles smaller than $0.002 \mu \mathrm{m}$ and can selectively 
remove dissolved constituents from wastewater. The particle rejection size and selectivity make it very useful for the removal of water-soluble plastics in wastewater treatment characterized by distinctive charge-based repulsion mechanism. Preparation of titanium/polyethyleneimine hybrid nanofiltration membranes has been reported by Zhang et al. [77]. The inclusion of titanium/polyethyleneimine to the matrix helped increased the stability of the membrane.

Nanofiltration membrane operates by selectively removing ions from solution. The membrane favors the removal of monovalent anions but retains multivalent anions. Parameters such as rejection of solute, solvent permeability and recovery are crucial for consideration when selecting materials for nanofiltration membrane. Most nanofiltration membranes are hydrophilic while their rejection capacity depends on charge, size and hydrophobicity. The operation of a simple nanofiltration system covers pretreatment, membrane processes and posttreatment. Nanofiltration membrane may also be used as a pretreatment step before reverse osmosis with the advantage of helping to minimize particulate fouling in reverse osmosis membrane. It can also help prevent scaling as well as lowering operating pressure which reduces cost in reverse osmosis. Most of the known nanofiltration membranes are produced from polymer [78-80]. A suitable polymer material for nanofiltration membrane production is expected to resist thermal and chemical attack with outstanding mechanical strength and capacity to form flat-sheet or hollow fiber structure. Apart from the polymeric membranes, studies have also revealed the production of ceramic membranes from alumina, zirconia, silica and oxide mixture [81-84]. They are preferred to the polymeric membranes because of the existence of lower fouling, narrow pore size distribution, chemical stability and higher porosity in ceramic membranes. The ceramic membrane is more preferred in water treatment due to the properties they exhibit, however, when it comes to cost, the polymeric membranes are preferred in industrial applications because the ceramic ones are more expensive. The outstanding performance of nanofiltration membrane such as low energy consumption, cost effectiveness and high permeability gives it wide application in different field. However, nanofiltration expresses some limitation like fouling, trade-off between flux and selectivity. Two major techniques used for the fabrication of nanofiltration membrane include phase-inversion process and interfacial polymerization. Figoli et al. [85] reported the preparation of flat sheet and hollow fiber membranes through phase inversion.

\subsection{Reverse Osmosis}

Reverse osmosis membrane technique is a water treatment process which applies pressure to force treated water through a semipermeable membrane to separate water from its constituents. The use of reverse osmosis membrane technology has played important role in the treatment of wastewater and water related issues because of its efficiency and most importantly due to the results obtained from the use of reverse osmosis in desalination of seawater [86]. Reverse osmosis can separate solute or particles with molecular weight less than $200 \mathrm{~g}$ mol-1 in solution by principle based on solution diffusion process in the presence of a very tight membrane. The process is carried out at about $7000-$ $15000 \mathrm{kPa}$. Reverse osmosis membrane operates on dynamic pressure to overcome osmotic pressure. Most reverse osmosis membranes are semipermeable polymeric layers adhering to support. They may be made of 
polyimide, cellulose acetate, polysulfones and polyamide. The reverse osmosis membrane is sensitive to $\mathrm{pH}$ and concentration change which is an indication that care must be taken to avoid contamination of the membrane. When using this membrane, it is important to ensure a pretreatment step to remove any suspended solids. Most reverse osmosis membranes are designed as a spiral-wound module as previously described [87]; however, there is also the hollow-fibre membrane modules but not so common. They are made of polymer such as polyamide and cellulose acetate. Reverse osmosis membrane is easy to operate with low chemical consumption. It is important to design the membrane such that it is less susceptible to fouling. Reverse osmosis membranes made of cellulose acetate can only operate at low $\mathrm{pH}$ (4 and 6), they are neutrally charged and are resistant to chlorine. Sometimes the effect of fouling and energy consumption may be reduced by increasing flow rate. Mass transfer in reverse osmosis membrane process occurs by solution-diffusion. The cut-off size for reverse osmosis modules is small which encourages fouling that may be irreversible fouling, therefore, currently, interest is shifting towards the combination of ultrafiltration and reverse osmosis membranes for the removal of pollutants in wastewater [88]. Ziajahromi et al. [43] also discussed the use of reverse osmosis for the removal of microplastics in water.

\subsection{Challenges and Further Perspectives}

There are reports on the presence of microplastics in the environment. Most reports on the presence of microplastics in water are not detailed and there is need to conduct more study in understanding the fate. It is also important to conduct more work to study the drinking water that originates from surface water where microplastic dominates [89, 90]. Most wastewater treatment plant lack the capacity to completely remove microplastic from water. It is a challenge that requires urgent attention. Focus should be on developing efficient membrane techniques for the complete removal of microplastics from wastewater treatment plants, which is a challenge in the complete removal of microplastics from industrial wastewater and municipal waste. Although some techniques are currently used for the characterization of plastics in the environment, some of these techniques such as FTIR and micro-Raman spectroscopy have shown lapses in some aspect of size measurement. This lapse calls for the development of a more robust technique that is more sensitive and sophisticated in characterizing microplastics because some present studies are pointing attention towards the presence of plastic in the environment at the nano levels (nanoplastics). Study on microplastic is still limited because there are questions to be answered such as the distribution of microplastic in the environment and factors that affect their distribution, transport pathways, establishment of an acceptable method of analysis and relevance and extent of impacts microplastics have on the environment and life [89, 91]. Although there are reports on the effect of microplastics on marine animals and plants but these reports are not detailed with scanty information on the effect on human, there is need to understand the particle toxicity of microplastics on human health and further study on aquatic organisms [92, 93]. The use of membrane has been so successful in the removal or treatment of water contaminated with microplastics. However, there is still a challenge with polymer sourced membrane fouling and chemical stability which requires 
attention. Although there has been some modification but they are expensive which makes the cost of treatment high. Therefore, there is need to focus on developing cheap and affordable means of reducing fouling in polymer sourced membranes or better pretreatment methods for handling wastewater samples before passing them through the membrane.

\subsection{CONCLUSION}

The presence of microplastics in water has become a serious environmental concern which requires monitoring and detailed attention. Currently, membrane technology is receiving attention in tackling this problem by serving as a means for removing microplastics in water. However, there are challenges of fouling and chemical instability which needs to be solved in such a way that will not make the use of membrane technology for the removal of microplastics in water expensive. The health challenges with microplastic are worrisome as this has been noticed in aquatic animals. There is need for more study to be conducted in order to understand the distribution and fate of microplastics in the environment as well as the detailed health hazard in human and other living organisms.

\section{REFERENCES}

[1] Nizzetto, L., Bussi, G., Futter, M. N., Butterfield, D., and Whitehead, P. G. 2016. A Theoretical Assessment of Microplastic Transport in River Catchments and Their Retention by Soils and River Sediments. Environmental Science: Processes and Impacts. 18(8): 1050-9. https://doi.org/10.1039/C6EM00
206D.

[2] Smith, M., Love, D. C., Rochman, C. M., and Neff, R. A. 2018. Microplastics in Seafood and the Implications for Human Health. Current Environmental Health Reports. 5(3): 375-386. https://doi.org/10.1007/s40572018-0206-z.

[3] Zhang, S., Wang, J., Liu, X., Qu, F., Wang, X., Wang, X., Li, Y., and Sun, Y. 2019. Microplastics in the Environment: A Review of Analytical Methods, Distribution, and Biological Effects. Trends in Analytical Chemistry. 111: 62-72. https://doi.org/10.1016/j.trac.201 8.12.002.

[4] Ahmad, M., Li, J.-L., Wang, P.D., Hozzein, W.-N., Li, W.-J. 2020. Environmental Perspectives of Microplastic Pollution in the Aquatic Environment: A Review. Marine Life Science and Technology. 2: 414-30. https://doi.org/10.1007/s42995020-00056-w.

[5] Mintenig, S., Int-Veen, I., Löder, M. G., Primpke, S., and Gerdts, G. 2017. Identification of Microplastic in Effluents of Waste Water Treatment Plants Using Focal Plane Array-based Micro-fourier-Transform Infrared Imaging. Water Research. 108: 365-72. https://doi.org/10.1016/j.watres.2 016.11.015.

[6] Olarinmoye, O. M., Stock, F., Scherf, N., Whenu, O., Asenime, C., and Ganzallo, S. 2020. Microplastic Presence in Sediment and Water of a Lagoon Bordering the Urban Agglomeration of Lagos, Southwest Nigeria. Geosciences. 10(12): 494. https://doi.org/10.3390/geoscienc es10120494. 
[7] Romeo, T., Pietro, B., Pedà, C., Consoli, P., Andaloro, F., and Fossi, M.C. 2015. First Evidence of Presence of Plastic Debris in Stomach of Large Pelagic Fish in the Mediterranean Sea. Marine Pollution Bulletin. 95(1): 358-61. https://doi.org/10.1016/j.marpolb ul.2015.04.048.

[8] Miranda, D. d. A., and de Carvalho-Souza, G. F. 2016. Are We Eating Plastic-ingesting Fish? Marine Pollution Bulletin. 103(1-2): 109-14. https://doi.org/10.1016/j.marpolb ul.2015.12.035.

[9] Leung, J., and Chan, K. Y. K. 2018. Microplastics Reduced Posterior Segment Regeneration Rate of the Polychaete Perinereis Aibuhitensis. Marine Pollution Bulletin. 129(2): 782-6. https://doi.org/10.1016/j.marpolb ul.2017.10.072.

[10] Ribeiro, F., Garcia, A. R., Pereira, B. P., Fonseca, M., Mestre, N. C., Fonseca, T. G., Ilharco, L. M. and Bebianno, M. J. 2017. Microplastics Effects in Scrobicularia Plana. Marine Pollution Bulletin. 122(1-2): 379-91.

https://doi.org/10.1016/j.marpolb ul.2017.06.078.

[11] Woods, M. N., Stack, M. E., Fields, D. M., Shaw, S. D., and Matrai, P. A. 2018. Microplastic fiber Uptake, Ingestion, and Egestion Rates in the Blue Mussel (Mytilus Edulis). Marine Pollution Bulletin. 137: 638-45. https://doi.org/10.1016/j.marpolb ul.2018.10.061.

[12] Talvitie, J., Mikola, A., Koistinen, A., and Setälä, O. 2017. Solutions to Microplastic Pollution-removal of Microplastics from Wastewater Effluent with Advanced Wastewater Treatment
Technologies. Water Research. 123: 401-7. https://doi.org/10.1016/j.watres.2 017.07.005.

[13] Barboza, L. G. A., Vieira, L. R., Branco, V., Figueiredo, N., Carvalho, F., Carvalho, C., and Guilhermino, L. 2018. Microplastics Cause Neurotoxicity, Oxidative Damage and Energy-related Changes and Interact with the Bioaccumulation of Mercury in the European Seabass, Dicentrarchus Labrax (Linnaeus, 1758). Aquatic Toxicology. 195: 49-57.

https://doi.org/10.1016/j.aquatox. 2017.12.008.

[14] Khan, R., Inam, M. A., Khan, S., Park, D. R., and Yeom, I. T. 2019. Interaction between Persistent Organic Pollutants and $\mathrm{ZnO}$ NPs in Synthetic and Natural Waters. Nanomaterials. 9(3): 472. https://doi.org/10.3390/nano9030 472.

[15] Fonte, E., Ferreira, P., and Guilhermino, L. J. 2016. Temperature Rise and Microplastics Interact with the Toxicity of the Antibiotic Cefalexin to Juveniles of the Common Goby (Pomatoschistus microps): Post-exposure Predatory Behaviour, Acetylcholinesterase Activity and Lipid Peroxidation. Aquatic Toxicology. 180: 173-185. https://doi.org/10.1016/j.aquatox. 2016.09.015.

[16] Wu, C., Zhang, K., Huang, X., and Liu, J. 2016. Sorption of Pharmaceuticals and Personal Care Products to Polyethylene Debris. Environmental Science and Pollution Research. 23(9): 8819-8826. https://doi.org/10.1007/s11356- 
016-6121-7.

[17] Ferrante, M., Napoli, S., Grasso, A., Zuccarello, P., Cristaldi, A., and Copat, C. 2019. Toxicology, Systematic Review of Arsenic in Fresh Seafood from the Mediterranean Sea and European Atlantic Coasts: A Health Risk Assessment. Food and Chemical Toxicology. 126: 322-331. https://doi.org/10.1016/j.fct.2019. 01.010 .

[18] Dris, R., Gasperi, J., Rocher, V., Saad, M., Renault, N., and Tassin, B. 2015. Microplastic Contamination in an Urban Area: A Case Study in Greater Paris. Environmental Chemistry. 12(5): 592-599.

https://www.publish.csiro.au/EN /EN14167.

[19] Renzi, M., Guerranti, C., and Blašković, A. 2018. Microplastic Contents from Maricultured and Natural Mussels. Marine Pollution Bulletin. 131: 248-251. https://doi.org/10.1016/j.marpolb ul.2018.04.035.

[20] Eriksen, M., Mason, S., Wilson, S., Box, C., Zellers, A., Edwards, W., Farley, H., and Amato, S. 2013. Microplastic Pollution in the Surface Waters of the Laurentian Great Lakes. Marine Pollution Bulletin. 77(1-2): 177182.

https://doi.org/10.1016/j.marpolb ul.2013.10.007.

[21] He, D., Luo, Y., Lu, S., Liu, M., Song, Y., and Lei, L. J. 2018. Microplastics in Soils: Analytical Methods, Pollution Characteristics and Ecological Risks. Trends in Analytical Chemistry. 109: 163-172. https://doi.org/10.1016/j.trac.201 8.10.006.

[22] Ballent, A., Corcoran, P.L., Madden, O., Helm, P. A., and Longstaffe, F. J. 2016 Sources and Sinks of Microplastics in Canadian Lake Ontario Nearshore, Tributary and Beach Sediments. Marine Pollution Bulletin. 110(1): 383-395. http://dx.doi.org/10.1016/j.marpo lbul.2016.06.037.

[23] Browne, M. A., Crump, P., Niven, S. J., Teuten, E., Tonkin, A., Galloway, T., and Thompson, R. J. 2011. Accumulation of Microplastic on Shorelines Woldwide: Sources and Sinks. Environmental Science and Technology. 45(21): 9175-9179. https://doi.org/10.1021/es201811 s.

[24] Almroth, B. M. C., Åström, L., Roslund, S., Petersson, H., Johansson, M., and Persson, N.K. 2018. Quantifying Shedding of Synthetic Fibers from Textiles; a Source of Microplastics Released into the Environment. Environmental Science and Pollution Research. 25(2): 11911199.

https://doi.org/10.1007/s11356017-0528-7.

[25] De Falco, F., Gullo, M.P., Gentile, G., Di Pace, E., Cocca, M., Gelabert, L., Brouta-Agnésa, M., Rovira, A., Escudero, R., Villalba, R., Mossotti, R., Montarsolo, A., Gavignano, S., Tonin, C., and Avella, M. 2018. Evaluation of Microplastic Release Caused by Textile Washing Processes of Synthetic Fabrics. Environmental Pollution. 236: 916-925. https://doi.org/10.1016/j.envpol. 2017.10.057.

[26] Bayo, J., Olmos, S., and LópezCastellanos, J. J. 2020. Microplastics in an Urban Wastewater Treatment Plant: The Influence of Physicochemical Parameters and Environmental Factors. 
Chemosphere. 238: 124593. https://doi.org/10.1016/j.chemos phere.2019.124593.

[27] Bayo, J., Olmos, S., LópezCastellanos, J., and Alcolea, A. 2016. Microplastics and Microfibers in the Sludge of a Municipal Wastewater Treatment Plant. International Journal of Sustainable Development and Planning. 11(5): $\quad$ 812-821. https://doi.org/10.2495/SDPV11-N5-812-821.

[28] Barnes, D. K., Galgani, F., Thompson, R. C., and Barlaz, M. 2009. Accumulation and Fragmentation of Plastic Debris in Global Environments. Philosophical Transactions B The Royal Society. 364(1526): 1985-1998.

https://doi.org/10.1098/rstb.2008. 0205 .

[29] Thompson, R. C. 2015. Microplastics in the Marine Environment: Sources, Consequences and Solutions. Marine Anthropogenic Litter. Cham. 185-200. https://doi.org/10.1007/978-3319-16510-3 7.

[30] Kosuth, M., Mason, S. A., and Wattenberg, E. V. 2018. Anthropogenic Contamination of Tap Water, Beer, and Sea Salt. PlosOne. 13(4): e0194970. https://doi.org/10.1371/journal.p one.0194970.

[31] Mason, S. A., Welch, V. G., and Neratko, J. J. 2018. Synthetic Polymer Contamination in Bottled Water. Frontiers in Chemistry. 6 : 407. https://doi.org/10.3389/fchem.20 18.00407.

[32] Mintenig, S., Löder, M., Primpke, S., and Gerdts, G. J. 2019. Low Numbers of Microplastics Detected in Drinking Water from
Ground Water Sources. Science of Total Environment. 648: 631635.

https://doi.org/10.1016/j.scitoten v.2018.08.178.

[33] McCormick, A., Hoellein, T. J., Mason, S. A., Schluep, J. and Kelly, J. 2014. Microplastic is an Abundant and Distinct Microbial Habitat in an Urban River. Environmental Science and Technology. 48(20): 1186311871.

https://doi.org/10.1021/es503610 r.

[34] Baldwin, A. K., Corsi, S. R., and Mason, S. A. 2016. Technology, Plastic Debris in 29 Great Lakes Tributaries: Relations to Watershed Attributes and Hydrology. Environmental Science and Technology. 50(19): 10377-10385.

https://doi.org/10.1021/acs.est.6b 02917.

[35] Lenaker, P. L., Baldwin, A. K., Corsi, S. R., Mason, S. A., Reneau, P. C., and Scott, J. W. 2019. Vertical Distribution of Microplastics in the Water Column and Surficial Sediment from the Milwaukee River Basin to Lake Michigan. Environmental Science and Technology. 53(21): 1222712237.

https://doi.org/10.1021/acs.est.9b 03850.

[36] Lambert, S., Sinclair, C., and Boxall, A. 2014. Occurrence, Degradation, and Effect of Polymer-based Materials in the Environment. Reviews of Environmental Contamination and Toxicology. 227: 1-53. https://doi.org/10.1007/978-3319-01327-5 1.

[37] Karami, A. J. C. 2017. Gaps in Aquatic Toxicological Studies of Microplastics. Chemosphere. 
184:

841-848.

https://doi.org/10.1016/j.chemos

phere.2017.06.048.

[38] Paul-Pont, I., Tallec, K., Gonzalez-Fernandez, C., Lambert, C., Vincent, D., Mazurais, D., ZamboninoInfante, J.-L., Brotons, G., Lagarde, F., Fabioux, C. J. 2018. Constraints and Priorities for Conducting Experimental Exposures of Marine Organisms to Microplastics. Frontiers in Marine Science. 5: 252. https://doi.org/10.3389/fmars.20 18.00252 .

[39] Masura, J., Baker, J., Foster, G., and Arthur, C. 2015. Laboratory Methods for the Analysis of Microplastics in the Marine Environment: Recommendations for Quantifying Synthetic Particles in Waters and Sediments. USA: National Oceanic and Atmospheric Administration.

[40] Lares, M., Ncibi, M. C., Sillanpää, M., and Sillanpää, M. J. 2018. Occurrence, Identification and Removal of Microplastic Particles and Fibers in Conventional Activated Sludge Process and Advanced MBR Technology. Water Research. 133: 236-246. https://doi.org/10.1016/j.watres.2 018.01.049.

[41] Horton, A. A., Walton, A., Spurgeon, D. J., Lahive, E., and Svendsen, C. J. 2017. Microplastics in Freshwater and Terrestrial Environments: Evaluating the Current Understanding to Identify the Knowledge Gaps and Future Research Priorities. Science of the Total Environment. 586: 127141.

https://doi.org/10.1016/j.scitoten v.2017.01.190.
[42] Rodríguez-Seijo, A., and Pereira, R. 2017. Morphological and Physical Characterization of Microplastics. Comprehensive Analytical Chemistry. Amsterdam: Elsevier. 49-66.

[43] Ziajahromi, S., Neale, P. A., Rintoul, L., and Leusch, F. D. 2017. Wastewater Treatment Plants as a Pathway for Microplastics: Development of a New Approach to Sample Wastewater-based Microplastics. Water Research. 112: 93-99. https://doi.org/10.1016/j.watres.2 017.01.042.

[44] Lusher, A. 2015. Microplastics in the Marine Environment: Distribution, Interactions and Effects. Marine Anthropogenic Litter. Cham: Springer. 245-307. https://doi.org/10.1007/978-3319-16510-3 10.

[45] Scherer, C., Brennholt, N., Reifferscheid, G., and Wagner, M. 2017. Feeding Type and Development Drive the Ingestion of Microplastics by Freshwater Invertebrates. Scientific Reports. 7: 17006. https://doi.org/10.1038/s41598017-17191-7.

[46] Weber, A., Scherer, C., Brennholt, N., Reifferscheid, G., and Wagner, M. 2018. PET Microplastics Do Not Negatively Affect the Survival, Development, Metabolism and Feeding Activity of the Freshwater Invertebrate Gammarus Pulex. Environmental Pollution. 234: 181-189. https://doi.org/10.1016/j.envpol. 2017.11.014.

[47] Boyle, K., and Örmeci, B. 2020. Microplastics and Nanoplastics in the Freshwater and Terrestrial Environment: A Review. Water. 12(9): 2633. https://doi.org/10.3390/w120926 
33.

[48] da Costa, J. 2017. Microplasticsoccurrence, Fate and Behaviour in the Environment. 'Comprehensive analytical chemistry'. (Eds APT RochaSantos, AC Duarte) Amsterdam: Elsevier. 1-24.

[49] Browne, M. A., Niven, S. J., Galloway, T. S., Rowland, S. J. and Thompson, R. C. 2013. Microplastic Moves Pollutants and Additives to Worms, Reducing Functions Linked to Health and Biodiversity. Current Biology. 23(23): 2388-2392. https://doi.org/10.1016/j.cub.201 3.10.012.

[50] Holland, E. R., Mallory, M. L., and Shutler, D. 2016. Plastics and Other Anthropogenic Debris in Freshwater Birds from Canada. Science of The Total Environment. 571: 251-258. https://doi.org/10.1016/j.scitoten v.2016.07.158.

[51] Deng, Y., Zhang, Y., Lemos, B., and Ren, H. 2017. Tissue Accumulation of Microplastics in Mice and Biomarker Responses Suggest Widespread Health Risks of Exposure. Scientific Repoerts. 7(1): 1-10. https://doi.org/10.1038/srep4668 7.

[52] Carr, K. E., Smyth, S. H., McCullough, M. T., Morris, J. F., and Moyes, S. 2012. Morphological Aspects of Interactions between Microparticles and Mammalian Cells: Intestinal Uptake and Onward Movement. Progress in Histochemistry and Cytochemistry. 46(4): 185-252. https://doi.org/10.1016/j.proghi.2 011.11.001.

[53] Andrades, R., Dos Santos, R. A., Martins, A. S., Teles, D., and Santos, R. G. 2019. Scavenging as a Pathway for Plastic Ingestion by Marine Animals. Environmental Pollution. 248: 159-165.

https://doi.org/10.1016/j.envpol. 2019.02.010.

[54] Malankowska, M., EchaideGorriz, C., and Coronas, J. 2021. Microplastics in Marine Environment: A Review on Sources, Classification, and Potential Remediation by Membrane Technology. Environmental Science: Water Research and Technology. 7: 243-58.

https://doi.org/10.1039/D0EW00 $802 \mathrm{H}$.

[55] Cole, M., Webb, H., Lindeque, P. K., Fileman, E. S., Halsband, C., and Galloway, T. S. 2014. Isolation of Microplastics in Biota-rich Seawater Samples and Marine Organisms. Scientific Reports. 4(1): 1-8. https://doi.org/10.1038/srep0452 8.

[56] Tagg, A., Harrison, J. P., Ju-Nam, Y., Sapp, M., Bradley, E. L., Sinclair, C. J., and Ojeda, J. J. 2017. Fenton's Reagent for the Rapid and Efficient Isolation of Microplastics from Wastewater. Chemical Communications. 53(2): 372-375. https://doi.org/10.1039/C6CC08 798A.

[57] Hurley, R. R., Lusher, A. L., Olsen, M., and Nizzetto, L. 2018. Validation of a Method for Extracting Microplastics from Complex, Organic-rich, Environmental Matrices. Environmental Science and Technology. 52(13): 7409-7417. https://doi.org/10.1021/acs.est.8b 01517.

[58] Rodrigues, M., Gonçalves, A., Gonçalves, F., Nogueira, H., Marques, J., and Abrantes, N. 
2018. Effectiveness of a Methodology of Microplastics Isolation for Environmental Monitoring in Freshwater Systems. Ecological Indicators. 89: $\quad 488-495$. https://doi.org/10.1016/j.ecolind. 2018.02.038.

[59] Hidayaturrahman, H., and Lee, T.-G. 2019. A Study on Characteristics of Microplastic in Wastewater of South Korea: Identification, Quantification, and Fate of Microplastics During Treatment Process. Marine Pollution Bulletin. 146: 696-702. https://doi.org/10.1016/j.marpolb ul.2019.06.071.

[60] Werber, J. R., Osuji, C. O., and Elimelech, M. J. 2016. Materials for Next-generation Desalination and Water Purification Membranes. Nature Reviews Materials. 1(5): 1-15. https://doi.org/10.1038/natrevma ts.2016.18.

[61] Lee, A., Elam, J. W., and Darling, S. B. 2016. Membrane Materials for Water Purification: Design, Development, and Application. Environmental Science: Water Research and Technology. 2(1): 17-42. https://doi.org/10.1039/C5EW00 159E.

[62] Ismail, A., and Goh, P. S. 2015. Microfiltration Membrane. Kobayashi, S., Mullen, K. (eds.). Encyclopedia of Polymeric Nanomaterials, Berlin Heidelberg: $\quad$ Springer-Verlag. 1250-1255.

[63] Reneker, D. H., and Chun, I. 1996. Nanometre Diameter Fibres of Polymer, Produced by Electrospinning. Nanotechnology. 7(3):

216.https://doi.org/10.1088/0957 $-4484 / 7 / 3 / 009$.

[64] Abadi, S. R. H., Sebzari, M. R.,
Hemati, M., Rekabdar, F., and Mohammadi, T. 2011. Ceramic Membrane Performance in Microfiltration of Oily Wastewater. Desalination. 265(1-3): 222-228. https://doi.org/10.1016/j.desal.20 10.07.055.

[65] Li, W., Ling, G.-Q., Huang, P., Li, K., Lu, H.-Q., Hang, F.-X., Zhang, Y., Xie, C.-F., Lu, D.-J., and $\mathrm{Li}$, J. H. 2016. Performance of Ceramic Microfiltration Membranes for Treating Carbonated and Filtered Remelt Syrup in Sugar Refinery. Journal of Food Engineering. 170: 41-49. https://doi.org/10.1016/j.jfooden g.2015.09.012.

[66] Hong, J., and He, Y. J. 2012. Effects of Nano Sized Zinc Oxide on the Performance of PVDF Microfiltration Membranes. Desalination. 302: 71-79.

https://doi.org/10.1016/j.desal.20 12.07.001.

[67] Moslehyani, A., Ismail, A. F., Matsuura, T., Rahman, M. A. and Goh, P. S. 2019. Recent Progresses of Ultrafiltration (UF) Membranes and Processes in Water Treatment. Membrane Separation Principles and Applications. Amsterdam: Elsevier. 85-110.

[68] Ma, B., Xue, W., Hu, C., Liu, H., Qu, J., and Li, L. 2019. Characteristics of Microplastic Removal Via Coagulation and Ultrafiltration During Drinking Water Treatment. Chemical Engineering Journal. 359: 159167.

https://doi.org/10.1016/j.cej.2018. 11.155.

[69] Ma, B., Xue, W., Ding, Y., Hu, C., Liu, H., and Qu, J. 2019. Removal Characteristics of Microplastics by Fe-based 
Coagulants During Drinking

Water Treatment. Journal of

Environmental Sciences. 78:

267-275.

https://doi.org/10.1016/j.jes.2018. 10.006 .

[70] Shahi, N. K., Maeng, M., Kim, D., and Dockko, S. 2020.

Removal Behavior of

Microplastics Using Alum

Coagulant and Its Enhancement Using Polyamine-coated Sand.

Process Safety and

Environmental Protection. 141:

9-17.

https://doi.org/10.1016/j.psep.20

20.05.020.

[71] Muthumareeswaran, M., Alhoshan, M., and Agarwal, G. P. 2017. Ultrafiltration Membrane for Effective Removal of Chromium Ions from Potable Water. Scientific Reports. 7(1): 1-12.

https://doi.org/10.1038/srep4142 3.

[72] Korus, I., and Loska, K. J. D. 2009. Removal of Cr (III) and Cr (VI) Ions from Aqueous Solutions by Means of Polyelectrolyte-enhanced

Ultrafiltration. Desalination. 247(1-3): 390-395. https://doi.org/10.1016/j.desal.20 08.12.036.

[73] Van der Bruggen, B., Vandecasteele, C., Van Gestel, T., Doyen, W., and Leysen, R. 2003. A Review of Pressure-driven Membrane Processes in Wastewater Treatment and Drinking Water Production. Environmental Progress. 22(1): 46-56. https://doi.org/10.1002/ep.67022 0116.

[74] Adham, S. Chiu, K.-P., and Lehman, G. 2006. Optimization of Membrane Treatment for Direct and Clarified Water
Filtration. American Water Works Association.

[75] Loo, S.-L., Fane, A. G., Krantz, W. B., and Lim, T.-T. 2012. Emergency Water Supply: a Review of Potential Technologies and Selection Criteria. Water Research. 46(10): 3125-3151.

https://doi.org/10.1016/j.watres.2 012.03.030.

[76] Santos, E. N., László, Z., Hodúr, C., Arthanareeswaran, G., and Veréb, G. 2020. Photocatalytic Membrane Filtration and Its Advantages Over Conventional Approaches in the Treatment of Oily Wastewater: A Review. Asia-Pacific Journal of Chemical Engineering. 15(5): e2533.

https://doi.org/10.1002/apj.2533.

[77] Zhang, H., Mao, H., Wang, J., Ding, R., Du, Z., Liu, J., and Cao, S. J. 2014. MineralizationInspired Preparation of Composite Membranes with Polyethyleneimine-Nanoparticle Hybrid Active Layer for Solvent Resistant Nanofiltration. Journal of Membrane Science. 470: 7079.

https://doi.org/10.1016/j.memsci. 2014.07.019.

[78] Han, L.-F., XU, Z.L., Yu, L.-Y., Wei, Y.-M., and Cao, Y. 2010. Performance of PVDF/multinanoparticles Composite Hollow Fibre Ultrafiltration Membranes. Iranian Polymer Journal. 19(7): 553-565.

[79] Saljoughi, E., Amirilargani, M., and Mohammadi, T. J. D. 2010. Effect of PEG Additive and Coagulation Bath Temperature on the Morphology, Permeability and Thermal/Chemical Stability of Asymmetric CA Membranes. Desalination. 262(1-3): 72-78. https://doi.org/10.1016/j.desal.20 
10.05.046.

[80] Li, X., Liu, H., Xiao, C., Ma, S., and Zhao, S. J. 2013. Effect of Take-up speed on Polyvinylidene Fluoride Hollow Fiber Membrane in a Thermally Induced Phase Separation Process. Journal of Applied Polymer Science. 128(2): 10541060.

https://doi.org/10.1002/app.3791 9.

[81] Harman, B., Koseoglu, H., Yigit, N., Beyhan, M., and Kitis, M. J. D. 2010. The Use of Iron OxideCoated Ceramic Membranes in Removing Natural Organic Matter and Phenol from Waters. Desalination. 261(1-2): 27-33. https://doi.org/10.1016/j.desal.20 10.05.052.

[82] Hofs, B., Ogier, J., Vries, D., Beerendonk, E. F., and Cornelissen, E. R. 2011. Comparison of Ceramic and Polymeric Membrane Permeability and Fouling Using Surface Water. Separation and Purification Technology. 79(3): 365-374.

https://doi.org/10.1016/j.seppur.2 011.03.025.

[83] Pendergast, M. M., and Hoek, E. M. V. 2011. A Review of Water Treatment Membrane Nanotechnologies. Energy and Environmental Science. 4(6): 1946-1971.

https://doi.org/10.1039/C0EE005 41J.

[84] Mohammadi, T., and Maghsoodloorad, H. 2013. Synthesis and Characterization of Ceramic Membranes (W-Type Zeolite Membranes). International Journal of Applied Ceramic Technology. 10(2): 365-75. https://doi.org/10.1111/j.17447402.2011.02749.x.
[85] Figoli, A., Marino, T. Simone, S. Di Nicolo, E., Li, X.-M., He, T., Tornaghi, S., and Drioli, E. 2014. Towards Non-toxic Solvents for Membrane Preparation: A Review. Green Chemistry. 16(9): 4034-4059. https://doi.org/10.1039/C4GC00 613E.

[86] Peters, T. 2010. Membrane Technology for Water Treatment. Chemical Engineering and Technology. 33(8): 1233-1240. https://doi.org/10.1002/ceat.2010 00139.

[87] Judd, S., and Jefferson, B. 2003. Membranes for Industrial Wastewater Recovery and Re-use. Elsevier.

[88] Ashfaq, M. Y., Al-Ghouti, M. A. and Zouari, N. 2020. Functionalization of Reverse Osmosis Membrane with Graphene Oxide and Polyacrylic Acid to Control Biofouling and Mineral Scaling. Science of the Total Environment. 736: 139500. https://doi.org/10.1016/j.scitoten v.2020.139500.

[89] Li, Y., Lu, Z., Zheng, H., Wang, J., and Chen, C. 2020. Microplastics in Surface Water and Sediments of Chongming Island in the Yangtze Estuary, China. Environmental Sciences Europe. $\quad 32(1)$ : 1-12. https://doi.org/10.1186/s12302020-0297-7.

[90] McEachern, K., Alegria, H., Kalagher, A. L., Hansen, C., Morrison, S., and Hastings, D. 2019. Microplastics in Tampa Bay, Florida: Abundance and Variability in Estuarine Waters and Sediments. Marine Pollution Bulletin. 148: 97-106. https://doi.org/10.1016/j.marpolb ul.2019.07.068.

[91] Stolte, A., Forster, S., Gerdts, G., Schubert, H. 2015. Microplastic 
Concentrations in Beach Sediments Along the German Baltic Coast. Marine Pollution Bulletin. 99(1-2): 216-229. https://doi.org/10.1016/j.marpolb ul.2015.07.022.

[92] Tsang, Y. Y., Mak, C. W., Liebich, C., Lam, S. W., Sze, E. T.-P., Chan, K. M. 2017. Microplastic Pollution in the Marine Waters and Sediments of Hong Kong. Marine Pollution Bulletin. 115(1-2): 20-28. https://doi.org/10.1016/j.marpolb ul.2016.11.003.

[93] Vianello, A., Boldrin, A., Guerriero, P., Moschino, V., Rella, R., Sturaro, A., and Da Ros, L. 2013. Microplastic Particles in Sediments of Lagoon of Venice, Italy: First Observations on Occurrence, Spatial Patterns and Identification. Estuarine, Coastal and Shelf Science. 130: 54-61. https://doi.org/10.1016/j.ecss.201 3.03.022. 